\title{
Criminal Offences against Public Health under THE CRIMINal Code of THE REPUBLIC OF SLOVENIA
}

\author{
Accepted \\ 6. 2.2020 \\ Revised \\ 17. 3. 2020 \\ Published \\ 24. 4. 2020 \\ VID JAKULIN \\ University of Ljubljana, Faculty of Law, Ljubljana, Slovenia, e-mail: \\ vid.jakulin@pf.uni-lj.si \\ CORRESPONDING AUTHOR \\ vid.jakulin@pf.uni-lj.si
}

Keywords

crimes,

contagious diseases

negligent medical

treatment,

illegal transplant,

quackery.

\begin{abstract}
The author discusses criminal offences against public health under the Criminal Code of the Republic of Slovenia. In this Chapter of the Criminal Code, the object of protection under criminal law is human health, i.e. the health of both individuals and people in general as a common (general) value. Although criminal offences against public health are statistically insignificant in the author's opinion, they are important for protecting human health as one of the most significant values protected by law. Given the rapid development of medicine, it may be expected that the need will arise in the future for some new incriminations. Modern law places an increasing importance on an injured person's approval for interference with his or her body, which will lead to a different way of assessing the completeness of the essence of several criminal offences, referred to in this Chapter of the Criminal Code.
\end{abstract}




\section{$1 \quad$ Introduction}

Human health is one of the major basic rights protected by criminal law. However, not all countries act in the same way to ensure protection of these rights. For example, in some countries, crimes against public health are compiled in a separate chapter of the Criminal Code (e.g. in Croatia, North Macedonia, Hungary, Slovenia, Serbia, Switzerland). In other countries, crimes against public health are compiled in a chapter which also deals with the protection of basic rights other than health, such as life (Czech Republic) or the environment (Norway). In yet other countries, however, provisions on public health protection are scattered across the Criminal Code (Austria, France, Italy, and Germany). Some countries (France, Germany) have a diversified secondary criminal law legislation in addition to the Criminal Code provisions.

In order to make it easier for my colleagues outside of Slovenia to draw comparisons between their and Slovenian legislation in this area, the author will canvass the current state of legislation in the Republic of Slovenia bearing on these issues.

Criminal offences against the public health are addressed in Chapter Twenty of the Slovenian Criminal Code (2008, hereinafter: KZ-1). Pursuant to KZ-1, the object of protection under criminal law is public health. Some authors believe that the object of protection is not the health of specific individuals, but rather health as a general, common good (value) of all people (Babić \& Marković, 2018: 160). Other authors consider that the objects of protection under criminal law, which is encompassed by $\mathrm{KZ}-1$, are both the health of specific individuals and the health of people in general (Cvitanović et al., 2018: 254). According to Valenčič and Korošec (2019: 47), most criminal offences addressed in KZ-1 relate to the protection of criminal law values that are either wholly disposable or disposable to a limited extent only. Regarding the criminal offences covered by KZ-1, this author's opinion is that it relates not only to the protection of the health of specific individuals but also to people's health as a common (general) value.

According to their consequences, the criminal offences mentioned above are similar to the acts against life and limb, and according to the degree of danger of extending the consequences to an indefinite number of individuals, they are similar to acts against general safety of people and property. These offences differ from said acts, 
however, in terms of the specific circumstances and how the acts are committed.

The criminal offences referred to in KZ-1 can be divided into four groups:

a) Acts that violate the measures for the suppression or prevention of contagious diseases. This group includes only the criminal offence of the spreading of contagious diseases (Article 177).

b) Criminal offences relating to improper work in the medical, health care field or alternative medical activities: failure to render medical aid (Article 178), negligent medical and alternative medical treatment (Article 179), illegal transplant of parts of human body and modification of the human genome (Article 181), reckless performance of pharmacological activities (Article 182), and careless inspection of meat for human consumption (Article 185).

c) Criminal offences prohibiting quackery and manufacture and trade in harmful remedies. This group includes the following: quackery (Article 180), manufacture and trade in harmful remedies (Article 183) and production and trade of tainted foodstuffs and other products (Article 184).

d) Criminal offences relating to drug abuse and the use of illicit substances in sport. This group includes the unlawful manufacture and trade of narcotic drugs, illicit substances in sport and precursors to the manufacture of narcotic drugs (Article 186) and rendering the opportunity for the consumption of narcotic drugs or illicit substances in sport (Article 187).

Similar divisions are discussed by Cvitanović et al. (2018: 258-259).

Six criminal offences referred to in the KZ-1 constitute general criminal offences, meaning that the perpetrator can include any individual whose status as an active perpetrator of a criminal offence is recognised by the legal order. Five criminal offences referred to in the KZ-1 constitute special criminal offences, meaning that the perpetrator can only be a person engaged in a particular occupation (e.g. a physician, a pharmacist, a veterinarian). 
The majority of the criminal offences referred to in the KZ-1, however, have a blanket disposition. This means that the description of a criminal offence in the Criminal Code does not capture the full content of the offence, but instead refers to other regulations that complement the disposition. In other words, while the Criminal Code defines all essential elements of a particular criminal offence, the content of only one of the legal elements is defined by another regulation that must be found looking outside the Criminal Code (Bavcon, Šelih et al., 2013: 193; also established by Cvitanović et al., 2018: 257; Babić \& Marković, 2018: 160; and Valenčič, 2019: 47).

The majority of the criminal offences referred to in the KZ-1 are criminal offences committed intentionally. Some of them are also punishable if they are committed through negligence. Negligent medical and alternative medical treatment (Article 179) and the reckless performance of pharmacological activities (Article 182) are criminal offences committed through negligence and that cannot possibly be committed intentionally. If the perpetrator acts with intent, the conduct would constitute another criminal offence (e.g. a serious bodily injury or even murder).

Negligent offences represent a special type of criminal offence that differ by their construction and structure from intentional offences. They are punishable only if specifically provided so by the Code.

Negligent offences have specific features, which should be specially highlighted. The consummation of a negligent offence is manifested by a breach of due care (i.e., breach of duty of care). This is of crucial importance because it is the perpetrator's failure to measure up to the duty of due care that constitutes the ethical basis for the punishability of these offences. The next important feature of negligent offences is the harm- inflicting consequence (harm done to the protected value), which is considered as an essential element in the structure of these offences. Another unique feature of these offences relates to the element of causal relationship. Specifically, a causal relationship between a breach of due care and the resulting prohibited consequence is treated differently than in the case of typical intentional offences. Culpability in negligent offences is assessed by the rules applied to prove the ordinary negligence (Bavcon, 2000: 152-154). The features mentioned above will be of assistance in analysing the provisions of Articles 179 and 182. 
The criminal offences covered by this Chapter of the KZ-1 account for 3.42 percent to 8.12 percent of the criminal offences processed by the courts in the Republic of Slovenia in the period 2000-2017. The statistics indicate the following number of adult and adolescent individuals convicted of criminal offences against public health in the Republic of Slovenia (Statistical Office of the Republic of Slovenia, 2019):

Table 1: Number of convicted of criminal offences against public health in the Republic of Slovenia

\begin{tabular}{|c|c|}
\hline Year & Number \\
\hline 2000 & 240 \\
\hline 2001 & 308 \\
\hline 2002 & 350 \\
\hline 2003 & 333 \\
\hline 2004 & 392 \\
\hline 2005 & 281 \\
\hline 2006 & 409 \\
\hline 2007 & 373 \\
\hline 2008 & 373 \\
\hline 2009 & 384 \\
\hline 2010 & 413 \\
\hline 2011 & 528 \\
\hline 2012 & 591 \\
\hline 2013 & 934 \\
\hline 2014 & 745 \\
\hline 2015 & 669 \\
\hline 2016 & 536 \\
\hline 2017 & 443 \\
\hline
\end{tabular}

Data from the same source show that 395 adult persons were convicted of crimes against public health in the Republic of Slovenia in 2017, of which 379 persons were convicted of crimes relating to the unlawful manufacture and trade of narcotic drugs, illicit substances in sport and precursors to the manufacture of narcotic drugs (Article 186) and 16 for crimes relating to rendering opportunity for the consumption of narcotic drugs or illicit substances in sport (Article 187). There were 
no convictions for other criminal offences referred to in this Chapter of the KZ-1. However, it should not be assumed from these statistics that other crimes referred to in this Chapter of the KZ-1 were not committed at all. It may be presumed that there is an extensive gap in people's awareness that they or their family members are victims of criminal acts (such as negligent medical treatment) and that individuals do not even report such acts to the prosecuting authorities.

Another rational explanation in support of the author's hypothesis that the official Government statistics regarding actual convictions likely mask the fact there are, in all probability, more crimes committed that simply do not result in conviction is the fact that it in practice it often is extremely challenging to prove such criminal acts.

\section{Acts that violate the measures for the suppression or prevention of contagious diseases}

\subsection{Spreading of Contagious Diseases (Article 177) ${ }^{1}$}

The perpetrator of this criminal offence could be anyone. In practice, it is often an authorised person of a company, state body or other organisation responsible for implementing the prescribed and imposed protective measures against contagious diseases (for more, see Valenčič, 2019: 49-50). A legal person may also be held responsible for such a criminal offence.

The criminal offences referred to in paragraphs one and two of Article 177 must be committed intentionally, and the one referred to in paragraph three can be committed through an act of negligence. The perpetrator of an intentionally committed offence, to be held criminally responsible, must be aware of the manner in which he or she should act respecting the relevant rules or orders and that his or her failure to do so will have consequences.

\footnotetext{
1 “(1) Whoever does not comply with regulations or orders, by which a competent authority has ordered a medical examination, disinfection, quarantine or other measures for the suppression or prevention of contagious diseases in human beings and thereby causes the spread of a contagious disease, shall be punished by a fine or sentenced to imprisonment for not more than one year. (2) The same punishment shall be imposed on anyone who does not comply with regulations or orders, by which a competent authority has ordered measures for the suppression or prevention of contagious diseases in animals and thereby causes the spread of a contagious disease to human beings. (3) Whoever commits the offence under paragraphs 1 or 2 of this Article by negligence shall be punished by a fine or sentenced to imprisonment for not more than six months. (4) If the act under paragraphs 1, 2 or 3 of this Article results in death of one or more persons, the perpetrator shall be sentenced to imprisonment for not more than eight years for the offence under paragraphs 1 or 2 and for not more than five years for the offences under paragraph 3."
} 
This is a blanket criminal offence, which refers to the provisions of the rules or orders for suppressing and preventing the contracting of contagious diseases in humans or diseases in animals, which can then be transmitted to humans.

This is a genuine criminal offence of omission, which is manifested by failing to comply with the prescribed or imposed measures. A criminal offence is deemed to have been committed only when the perpetrator causes by his or her actions the spread of a contagious disease, i.e. causes the infection of at least one more person. The Contagious Diseases Act defines the diseases that are considered contagious (Deisinger, 2017: 313-314).

\section{Criminal offences relating to improper work in the medical, health care or alternative medical activities}

\subsection{Failure to Render Medical Assistance (Article 178) ${ }^{2}$}

The perpetrator of this criminal offence can only be a physician or other healthcare professional, notably the one who actually provides healthcare service (Deisinger, 2017: 316). This view is also shared by Mrčela and Vuletić (2019: 38), who justify it by noting that any interpretation of the criminal offence of failure to render medical aid to the contrary would result in an excessively wide circle of potential perpetrators (e.g. retired physicians or persons who actually have medical qualifications but do not practice medicine). An opposite view is advocated by Korošec and Balažic (2019: 67), who believe that the reach of this Article can extend not only to a medicine graduate who lacks a valid medical licence and but even to a person with a fake medical degree or a forged specialisation certificate whose medical licence is, consequently, void. A legal person may also be held responsible for such a criminal offence.

\footnotetext{
2 “(1) A doctor or any other medical employee who breaches the terms of his professional duty by failing to render aid to a patient or any person whose life is in danger shall be sentenced to imprisonment for not more than one year. (2) The act referred to in the preceding paragraph shall not be unlawful if the physician withdraws a method of treatment, surgery or medical procedure at the explicit written request of the patient or other person who is able to make a decision about himself and also refuses help after being informed about the necessity of treatment and possible consequences of refusing it, and also after the physician has again tried to persuade such a person to change his decision."
} 
Such a criminal offence can only be committed with direct intent; mere negligence will not suffice to be found criminally liable. To be found liable, the perpetrator must also be aware of the imminent danger of death for other persons. This is a genuine criminal offence of omission. Physicians and other medical professionals have a professional duty to provide assistance to patients and other persons facing imminent danger of death. In this context, the essential provisions are those of the Medical Practitioners Act ${ }^{3}$ and of the Code of Ethics of Healthcare and Nursing. ${ }^{4}$

The offence is committed by failing to provide medical assistance, regardless of whether it was explicitly required. To prove that a criminal offence has been committed, it suffices to establish that such assistance was necessary, and that the physician or other medical professional was aware of the fact. The criminal offence results from a definitive failure to provide medical assistance.

A danger to the life of the patient or another person must objectively exist and must be imminent, i.e. specific. One should establish the existence of an imminent danger of death and the necessity of medical assistance that could have been provided by a physician or other medical professionals. Moreover, it should be noted that a physician or other medical professional is obliged to provide only the kind of assistance for which he or she is qualified. For instance, a medical professional other than a physician cannot be required to provide specialist medical assistance. The form of assistance a physician or other medical professional is legally required to provide is that which is considered necessary to help avert, reduce or postpone the risk of death. The criminal offence can be committed by the very omission of assistance, irrespective of whether such failure actually had negative consequences for a patient or other person.

Paragraph two provides for an exception to liability in the case of a physician who, under precisely defined circumstances, fails to provide medical assistance. Special attention should be given to the fact that the exception applies only to physicians and not to other medical professionals (Deisinger, 2017: 316-317).

\footnotetext{
${ }^{3}$ See Article 43 of the Medical Practitioners Act, unofficial consolidated text 10 of 27 July 2018, available at the website of the National Assembly of the Republic of Slovenia https://imss.dzrs.si/imis/bd9ec8f10e86be91e5ed.pdf Accessed on 6 April 2019.

${ }^{4}$ Official Gazette of the Republic of Slovenia [Uradni list RS], No 13/17.
} 
According to Deisinger (2017: 317), a criminal offence against life and limb may be committed intentionally or negligently in the event of consequences (a serious or a particularly serious bodily injury or death of the person in peril). However, this author's view is that when a physician fails to provide medical assistance or treatment, even though he or she is aware that it would lead to a patient's death, the two situations must be considered separately. If a physician fails to provide medical assistance or treatment after a patient refused the proposed assistance or treatment under Article 30 of the Patients' Rights Act ${ }^{5}$, it is not a criminal offence even though the omission of assistance resulted in the patient's death. Such omission in this circumstance does not, however, constitute a criminal offence because the physician's act is not contrary to the law.

The situation is different when a physician fails to provide medical assistance or treatment without the patient's knowledge and consent. In such case, however, such failure could constitute a criminal offence of failure to render medical assistance under Article 178. If a physician is aware that failure to render medical assistance could cause the death of a patient and yet fails to provide such assistance even though he or she could have thereby saved the patient's life, such an act could constitute a manslaughter under Article 116.

\subsection{Negligent medical and alternative medical treatment (Article 179) ${ }^{6}$}

This is a special criminal offence that can only be committed by a physician, other medical professional (nurse, midwife, medical technician, theatre nurse, etc.) or an alternative medicine practitioner who actually performs health care, i.e. licensed alternative medicine activity (Pitako, Valenčič, Korošec \& Balažic, 2019: 96-97). A legal person may also be held responsible for such a criminal offence.

\footnotetext{
5 The Medical Practitioners Act, unofficial consolidated text 1 of 9 November 2017, available at the website of the National Assembly of the Republic of Slovenia https://imss.dz-rs.si/imis/47910f3596c44871833b.pdf Accessed on 6 April 2019.

6 "(1) A doctor who in the course of performing medical activities does not act in conformity with his code of professional conduct, thereby causing the substantial impairment of health of a patient, shall be sentenced to imprisonment for not more than three years. (2) The same punishment shall be imposed on (a)any other medical employee who, owing to negligence in the course of performing his duties does not act in conformity with his code of professional conduct, thus causing a substantial impairment of the patient's health, or (b)an alternative medical healer who in the course of performing his duties inappropriately chooses or uses an alternative medicine system or method, thus causing a substantial impairment of the patient's health. (3) If the act under paragraphs 1 or 2 results in the death of a person, the perpetrator shall be sentenced to imprisonment between one and eight years."
} 
This is a negligent criminal offence that cannot possibly be committed intentionally. If a physician, other medical professional or alternative medicine practitioner acted with intent to cause bodily injury or death of the person that he or she is treating, it would not constitute a criminal offence of negligent medical and alternative medical treatment but rather an intentional act causing a serious or a particularly serious injury, and, in the case of death, it would constitute manslaughter or murder.

The central idea behind negligent criminal offences is the fact there is an underlying duty owed by the actor that is found in the ethical obligations of the actor's profession. The failure to comply with this underlying duty (or duties), which is essential in these types of criminal offences, provides the underlying rationale for criminalizing such failures and hence punishing the noncompliant actor. The violation of an act of duty is the basis for establishing the existence of a causal link between the perpetrator's actions and the resulting unlawful consequences and the guilt for the offence committed. In each particular case, in order to determine whether a physician, other medical professional or alternative medicine practitioner is guilty of such offence, we must look wheather the physician, other medical professional or alternative medicine practitioner violated their act of duty and that such violation caused a considerable deterioration in the health of the patient.

A problem is represented by the fact that the law provides that a physician, other medical professional or alternative medicine practitioner violated the rules of their respective professions through negligence. What if they violated the rules of the profession deliberately (with intent), but with the best interests of the patient in mind? Let us consider, for example, a neurosurgeon operating on a person with severe head injuries. The surgeon finds a massive cavernous sinus haemorrhage. Although the surgeon knows that cavernous sinus should be avoided, ${ }^{7}$ he nevertheless decides to try to save the injured person. If his attempt is successful, there is no criminal offence. If not, and if the injured person dies despite the surgeon's efforts, the author believes that such action should not constitute negligent treatment. The reason for this contention is that in such a case, the injured person's death is not the result of a negligent violation of professional rules.

\footnotetext{
${ }^{7}$ Such view of the medical science and profession was held in the past.
} 


\subsection{Illegal transplant of parts of human body and modification of the human genome (Article 181) ${ }^{8}$}

The criminal offences referred to in paragraphs one through four of this Article can only be committed by a physician, and the criminal offences referred to in paragraphs five and six of this Article by anyone (Korošec, 2019: 121-122). A legal person may also be held responsible for this criminal offence. This criminal offence can only be committed with intent.

This is a blanket criminal offence. It is based on the Convention for the Protection of Human Rights and Dignity of the Human Being with regard to the Application of Biology and Medicine and on the protocols to this Convention. ${ }^{9}$ This area is also regulated by Directive 2010/53/EU of the European Parliament and of the Council of 7 July 2010 on standards of quality and safety of human organs intended for transplantation and the Corrigendum thereto and the Commission Implementing Directive 2012/25/EU of 9 October 2012 laying down information procedures for

\footnotetext{
8 “(1) A doctor who, in not conforming with his code of professional conduct, removes a part of the human body from or transplants a part of the body to a patient shall be sentenced to imprisonment for not less than six months and not more than five years. (2) A doctor who for the purpose to perform a transplant removes a part from the human body prior to the death of that patient being established in the proper manner shall be punished to the same extent. (3) The sentence under paragraph 1 shall also apply to the doctor, who illegally removes germ cells, handles them in a prohibited manner, or violates the anonymity of a germ cell donor. (4) A doctor who, for the purpose to perform a transplant removes a part from the body of a patient or who transplants a part of the body of a patient without having obtained prior statutory consent from the donor or the recipient of the part of the body or from their statutory representatives, or when, contrary to the prescribed procedures, stores or uses the removed part of the human body for some other purpose shall be sentenced to imprisonment for not less than three months and not more than five years. (5) Any person who attempts to perform or performs the procedure, the purpose of which is to modify the human genome and which is not performed for preventive, diagnostic, or therapeutic purposes, or with the goal to implement changes into the genome of future generations shall be sentence to imprisonment for not more than five years. (6) The same punishment under the preceding paragraph shall be imposed on any person who removes or obtains a removed part of the human body, for which the donor receives payment, who has the removed part of the human body illegally at his disposal, who uses or attempts to use the human body or its parts with the purpose to gain property benefits, or who unjustifiably and for payment serves as an agent for providing transplants of parts of the body of a living or a deceased person."

9 - Convention for the Protection of Human Rights and Dignity of the Human Being with regard to the Application of Biology and Medicine: Convention on Human Rights and Biomedicine ETS No. 164, 04. 04. 1997.

- Additional Protocol to the Convention for the Protection of Human Rights and Dignity of the Human Being with regard to the Application of Biology and Medicine, on the Prohibition of Cloning Human Beings ETS No. 168, 12. 01. 1998.

- Additional Protocol to the Convention on Human Rights and Biomedicine concerning Transplantation of Organs and Tissues of Human Origin ETS No. 186, 24. 01. 2002.

- Additional Protocol to the Convention on Human Rights and Biomedicine concerning Biomedical Research CETS No. 195, 25.1.2005.

- Additional Protocol to the Convention on Human Rights and Biomedicine concerning Genetic Testing for Health Purposes CETS No. 203, 27. 11. 2018.

Slovenia has ratified Convention and all Additional Protocols to the Convention.
} 
the exchange, between Member States, of human organs, intended for transplantation. Slovenia, as an EU Member State, is bound by the provisions of these Directives.

Relevant provisions regulating this criminal offence are set forth in the Acquisition and Transplantation of Parts of the Human Body for Treatment Purposes Act (2015). Various provisions of this Act lay down rules from which it can be determined whether a physician acted following the rules of the medical science and profession.

The criminal offence referred to in paragraph one of this Article can be committed in two ways. The first way consists of removing a part from the body of a living person, and the second was consists of its transplantation into the body of another person. Although the operation is in both cases performed by a surgeon, it does not constitute two concurrent criminal offences but instead a single criminal offence, since the criminal offence referred to in paragraph one consists of both the removal of a body for transplantation and its transplantation to another body, which is unlawful according to the medical science. The concurrence of these two criminal offences is, therefore, fictitious.

Paragraph two of Article 181 defines as a criminal offence the removal of a part from the human body for transplantation before death has been duly confirmed. Paragraph three of this Article defines the illegal removal of germ cells. Any such removal is illegal without a donor's written consent and when the requirements pertaining to statutorily required personal data, confidentiality and safe processing are violated.

Paragraph four of Article 181 defines a milder form of a criminal offence. It pertains to the removal of a part of a human body for transplantation or transplantation of a body part to another person performed in accordance with the rules of the medical science and profession, but without the appropriate prior consent of the donor and the recipient. Another form of criminal offence is the illegal storage of a removed part of a human body or its use for a purpose other than the one originally contemplated. 
Paragraph five of Article 181 defines the criminal offence of illegal modification of the human genome. The perpetrator of this criminal offence may be anyone attempting to modify or actually modifying the human genome.

The criminal offence referred to in paragraph six of Article 181 takes several forms. Punishment is imposed on anyone who obtains a removed part of a human body from the donor for payment and the trading in human body parts or intermediation in the trade in body parts of living and dead persons for payment (Deisenger, 2017: 324-326).

\subsection{Reckless performance of pharmacy service (Article 182) ${ }^{10}$}

This is a special criminal offence. It may only be committed by a pharmacist or another person authorised to dispense medicinal products. A legal person may also be held responsible for such a criminal offence.

This is a negligent criminal offence, which has all the characteristics of such type of criminal offence.

This is a blanket criminal offence. Consideration of the provisions of the Pharmacy Services Act (2016) are essential for assessing the actions taken by a pharmacist or the other person since those provisions set forth the underlying rules of the pharmaceutical science and profession. Only through an evaluation of those underlying rules can a determination be made regarding whether a person acted in accordance with or contrary to them.

A criminal offence is deemed to have been committed when a pharmacist or any other person authorised to issue medicines acts contrary to the rules of the pharmaceutical science and profession and thus causes a substantial impairment of a person's health through negligence. No criminal offence is deemed to have been committed if no significant impairment of a person's health occurs. The question arises, however, whether this is the most appropriate solution.

\footnotetext{
10 "A chemist or any other person authorised to issue medicines, who by negligence does not prepare the prescribed quantity or proportion of a medicine, or who issues a medicine or substance other than that prescribed, or in the preparation or issuing of medicines acts in any other way contrary to his code of professional conduct, thus causing a substantial impairment of a person's health shall be sentenced to imprisonment for not more than two year."
} 
Let us consider, for example, a pharmacist who negligently issues a wrong medicinal product, and which has no particular effect on the recipient's health. Since the medicine causes no significant deterioration in the person's health, this would not imply a criminal offence although the correct medication could have significantly alleviated the patient's suffering and lead to the his or her complete recovery within a week. The author contends that in such an instance it would be reasonable to define such an action as a criminal offence, since, due to the pharmacist's negligence, the patient would suffer longer than necessary with regard to the nature of the disease.

\subsection{Careless inspection of meat (Article 185) ${ }^{11}$}

This is a special criminal offence. It may only be committed by a veterinarian or a person authorised to inspect slaughter animals or meat intended for human consumption. A legal person may also be held responsible for such a criminal offence. This is a life-endangering criminal offence. The abstract risk to human life provides sufficient justification for the existence of such a criminal offence, which can be committed either intentionally or through negligence. According to Deisinger (2017: 334), given the nature of the criminal offence it most often will be committed through acts of negligence, and only intentionally in exceptional situations. By way of example, if the perpetrator acts with direct intent, the actual nature of one of the criminal offences against life and limb would be evident. Mervič (2019: 172) believes the opposite. In her opinion, the basic form of the criminal offence referred to in paragraph one of Article 185 can only be committed with (direct or eventual) intent. However, she also maintains that the perpetrator's intent can only be determined in relation to the violation, not in relation to the consequence of the perpetrator's action, which is the placing on the market meat hazardous for human health. In the event of a perpetrator's (direct or eventual) intent in relation to such consequence, there would be grounds for an appropriate criminal offence against life and limb or even for a terrorist criminal offence. This view is in line with Deisinger's observation and in this author's view is the better founded interpretation of Article 185. Let us imagine a case where a veterinarian fails to inspect meat with direct intent and

\footnotetext{
11 “(1) A veterinary surgeon or person responsible for inspecting livestock and meat intended for food production who carelessly and without proper regard performs the inspection or, contrary to relevant regulations, does not perform the inspection and thereby facilitating the trade of meat dangerous to human health shall be sentenced to imprisonment for not more than one year. (2) Whoever commits the offence under the preceding paragraphs by negligence shall be punished by a fine or sentenced to imprisonment for not more than six months."
} 
accepts that (eventual intent) meat that is hazardous for human health is placed on the market due to his or her omission of duty. If the veterinarian consciously and willingly facilitates the sale of the meat he or she knows is hazardous for human health, this would actually represent the causing of a general emergency pursuant to Article 314, and possibly also one of the criminal offences against life and limb.

This is a blanket criminal offence. The issuance of meat inspection authorisations is governed both by the Veterinary Practice Act (2001) and several implementing bylaws. These are important since, for the existence of a criminal offence, it must. Do you want to keep should, or instead must? Should implies some degree of discretion while must means mandatory. Be proved that the perpetrator failed to comply with them. The criminal offence can be committed by either action or failure to act. A veterinarian or other authorised person may carelessly inspect livestock or meat intended for human consumption, or may fail to inspect and thus facilitate the marketing of spoiled meat. The result of this criminal offence is spoiled meat, which is then placed on the market. This feature of meat must be present during the inspection or during the omission thereof. If meat becomes spoiled after the inspection, this criminal offence does not apply (Deisinger 2017: 334-335).

\section{$4 \quad$ Criminal offences prohibiting quackery and manufacture and trade in harmful remedies}

\subsection{Quackery (Article 180) ${ }^{12}$}

Quackery consists of the performance of treatment without the required qualifications. The perpetrator of this criminal offence may be any person lacking the qualifications required for a physician or alternative medical professional. Pitako, Valenčič and Korošec (2019: 110) believe that quackery nonetheless constitutes a special criminal offence (delictum proprium), since the perpetrator cannot be a physician or another person having the required qualifications and the professional

\footnotetext{
12 “(1) Any person who performs medical treatment or alternative medical treatment, even though he does not have the prescribed qualifications, and therefore prevents that the patient seeks medical assistance in due time, shall be sentenced to imprisonment between six months and five years. (2) The perpetrator of the offence referred to in the preceding paragraph, who causes serious harm to a person's health, shall be sentenced to imprisonment between six months and eight years. (3) If the act under paragraph 1 results in the death of a patient, the perpetrator shall be sentenced to imprisonment between one and ten years. (4) Equipment intended or used for the treatment referred to in paragraph 1 of this Article shall be seized."
} 
knowledge to perform a medical activity or to provide medical assistance, and not even a duly registered alternative medicine practitioner. Such a criminal offence can be committed with intent.

The criminal offence is deemed to have been committed if the perpetrator engages in providing medical treatment. It generally means that such a person continuously provides treatment to several persons. Exceptionally, the very initiation of such treatment to a single patient may be subject to criminal sanctions under circumstances when it can be proved that such activity is likely to be continued. The foundational conditions necessary for the commission of such a criminal offence are the admission of a patient in need of medical assistance coupled with the quack doctor failing to inform the patient to timely seek proper medical assistance. The same applies to an alternative medicine practitioner who lacks the qualifications to perform his or her activity. The alternative medicine practitioners' persuasion of a patient not to seek proper medical assistance also constitutes this criminal offence.

Paragraphs two and three of Article 180 define criminal responsibility for graver consequences - significant harm to human health or even death. In such a case, the perpetrator's negligence must be proved in relation to the graver consequence.

Paragraph four of Article 180 defines the obligatory seizure of all accessories that were intended to be used or were actually used in the "treatment" (Deisinger, 2017: $322)$. 


\subsection{Manufacture and trade in harmful remedies (Article 183) ${ }^{13}$}

This criminal offence may be committed by any person who manufactures, sells or otherwise supplies medicines or other medical remedies hazardous for health. Such a criminal offence is committed with intent or through negligence. The objects of this criminal offence are medicines or other medical remedies, which are hazardous for health. The manufacture and trade in medicines or other medical remedies are regulated both by the Medicinal Products Act (2014) and the Medical Devices Act (2009). The preliminary condition for establishing the existence of a criminal offence is that medicines or other medical remedies are hazardous for health. Their harmfulness must be established. For instance, the finding that the expiry date of medicines has been reached alone is not enough, since medicines do not automatically become hazardous for health after the expiry date.

Paragraph two of Article 183 prohibits the acquisition, processing or distribution of infected blood and other tissues or of medical remedies produced on the basis thereof.

Paragraphs four and five of Article 183 define the responsibility for graver consequences - serious or particularly serious bodily injury or the corresponding impairment of health or death of one or more persons. In such cases, the perpetrator's negligence must be proved in relation to a graver consequence.

Manufacture and trade in harmful foodstuffs or other products constitute a criminal offence under Article 184, which is discussed below.

\footnotetext{
13 “(1) Whoever manufactures, sells or otherwise supplies medicines or other medical remedies dangerous to health shall be sentenced to imprisonment for not more than eight years.

(2) Whoever is engaged in the extraction, preparation or disposing of infected blood or other tissue or therefrom derives remedies shall be punished to the same extent. (3) Whoever commits the offence under paragraphs 1 or 2 of this Article by reason of negligence shall be sentenced to imprisonment for not more than one year. (4) If serious or grievous bodily harm or a corresponding impairment of health of at least one person has been caused by the committing of any of the offences under paragraphs 1, 2 or 3 of this Article, the perpetrator shall be sentenced to imprisonment for not more than ten years for the offence under paragraphs 1 or 2, while for the offence under paragraph 3 he shall be sentenced to imprisonment for not more than five years. (5) If the offence under paragraphs 1, 2 or 3 of this Article results in death of one or more persons, the perpetrator shall be sentenced to imprisonment between one and fifteen years for the offence under paragraphs 1 or 2 and between one and ten years for the offence under paragraph 3."
} 


\subsection{Production and trade of tainted foodstuffs and other products (Article 184) ${ }^{14}$}

This criminal offence may be committed by whoever produces, sells or otherwise supplies foodstuffs hazardous for human health, thus causing a risk to human life or health. Such a criminal offence is committed with intent or through negligence. This is a life-endangering criminal offence. The existence of a criminal offence shall be based on a concrete risk to human life or health. ${ }^{15}$ Mervic (2019: 159) contends that the legislator bases the prohibition referred to in paragraph one of this Article as an abstract life-endangering offence with a concrete risk to the protected good as (nonauthentic) objective criminality condition, and the criminal offence referred to in paragraph two as an abstract life-endangering offence, where an abstract risk to human health suffices for the existence of a criminal offence. Spoiled foodstuffs must be hazardous for human health. If a foodstuff is not hazardous for human health, the act does not constitute a criminal offence.

Paragraph two of Article 184 provides that whoever produces, sells or otherwise places on the market products for personal care, toys or similar products for mass consumption, which are dangerous to human health, shall be punished to the same extent. Paragraphs four and five of Article 184 define the responsibility for graver consequences of a serious or particularly serious bodily injury or the corresponding impairment of health or death of one or more persons. In such cases, the perpetrator's negligence in relation to the graver consequence must be proved. Paragraph six of Article 184 lays down the obligation to seize harmful foodstuffs and other products (Deisinger, 2017: 331-333).

\footnotetext{
14 “(1) Whoever produces, sells or otherwise supplies foodstuffs dangerous to human health, thus causing danger to human life or health shall be sentenced to imprisonment for not more than three years. (2) Whoever produces, sells or otherwise puts on the market products for personal care, toys or similar products for mass consumption, which are dangerous to human health, shall be punished to the same extent. (3) Whoever commits the offence under paragraphs 1 or 2 of this Article by reason of negligence shall be sentenced to imprisonment for not more than one year. (4) If serious or grievous bodily harm or a corresponding impairment of health of at least one person have been caused by the committing of any of the offences under paragraphs 1, 2 or 3 of this Article, the perpetrator shall be sentenced to imprisonment for not more than eight years for the offence under paragraphs 1 or 2 , while for the offence under paragraph 3 he shall be sentenced to imprisonment for not more than five years. (5) If the offence under paragraphs 1, 2 or 3 of this Article results in death of one or more persons, the perpetrator shall be sentenced to imprisonment between one and twelve years for the offence under paragraphs 1 or 2 and between one and eight years for the offence under paragraph 3. (6) Tainted foodstuffs and other products shall be seized."

15 Deisinger (2017: 332) has a different opinion.
} 
Criminal offences relating to drug abuse and use of illicit substances in sport

\subsection{Unlawful manufacture and trade of narcotic drugs, illicit substances in sport and precursors to manufacture narcotic drugs (Article 186) ${ }^{16}$}

This criminal offence is based on several international acts. The oldest acts are those adopted by the United Nations Organisation: the Single Convention on Narcotic Drugs of 1961, as amended by the Protocol of 1972, the Convention on Psychotropic Substances of 1971, and the United Nations Convention on Combating Illicit Trafficking of Narcotic Drugs and Psychotropic Substances. The EU adopted a Council Framework Decision 2004/757/PNZ of 25 October 2004 laying down minimum provisions on the constituent elements of criminal acts and penalties in the field of illicit drug trafficking. Illicit substances in sport are prohibited by the International Convention against Doping in Sport (2005). Such a criminal offence may be committed by anyone and can only be committed with intent.

Paragraph one of Article 186 includes several alternative offences relating to the manufacture, trade or any other form of placing on the market of illicit drugs and illicit substances in sport. Such actions become criminal offences when they are carried out with an undue cause. Šepec (2019: 183) concludes that the legislator used verbs in the imperfective form to describe the offences, which means that it constitutes a collective offence, which covers many activities or repeated actions.

\footnotetext{
16 “(1) Whoever unlawfully manufactures, processes, sells or offers for sale plants or substances, which are classified as narcotic drugs or illicit substances in sport, or whoever purchases, keeps or transports such drugs or substances with a view to reselling and placing them on the market, or the precursors, which are used to manufacture narcotic drugs, shall be sentenced to imprisonment for not less than one and not more than ten years. (2) Whoever sells, offers for sale or hands out free of charge narcotic drugs, or illicit substances in sport or precursors to manufacture narcotic drugs to a minor, mentally disabled person, person with a temporary mental disturbance, severe mental retardation or person who is in the rehabilitation, or if the offence is committed in educational institutions or in immediate vicinity thereof, in prisons, military units, public places or public events, or if the offence under paragraph 1 is committed by a civil servant, priest, doctor, social worker, teacher or educator and thereby exploits his position, or whoever in order to commit the mentioned offence uses minors shall be sentenced to imprisonment between three and fifteen years. (3) If an offence from paragraphs 1 or 2 was committed within a criminal organisation for the committing of such criminal offences, or if the perpetrator of this offence organised a network of resellers or agents, the perpetrator shall be sentenced to imprisonment between five and fifteen years. (4) Whoever without an authorisation manufactures, purchases, possesses or furnishes other persons with the equipment, substances or precursors, which are to his knowledge intended for the manufacture of narcotic drugs or illicit substances in sport, shall be sentenced to imprisonment for not less than six months and not more than five years. (5) Narcotic drugs or illicit substances in sport and the means of their manufacture shall be seized. The means of transport used for the transport and storage of drugs or illicit substances in sport shall be seized if they have a specially adapted space for the transport and storage of drugs or illicit substances in sport or if their owner knew or should have known that they will be used for such a purpose."
} 
This means that, in the case of several criminal offences of the same type, the concurrence among them is fictitious, i.e. a single criminal offence.

The use of illicit drugs in the Republic of Slovenia is not a criminal offence. The objects of a criminal offence are the substances declared as illicit drugs.

Paragraph two of Article 186 provides for a qualified form of a criminal offence, which is committed in the case of sensitive victims or perpetrators that abuse their position, or if the offence is committed in a specific location. Paragraph three of Article 186 also provides for a qualified form of a criminal offence, which is committed in a criminal organisation or if the perpetrator organises a network of traffickers or intermediaries (Deisinger, 2017: 336-338).

\subsection{Rendering opportunity for consumption of narcotic drugs or illicit substances in sport (Article 187) ${ }^{17}$}

The perpetrator of this criminal offence could be anyone. Such a criminal offence can only be committed with direct intent.

A criminal offence is deemed to be completed when a narcotic drug or illicit substance is actually consumed by another person. The person who uses a narcotic drug or illicit substance is not committing a criminal offence. A criminal offence is committed only if the object of the offence is a narcotic drug or an illicit substance in sport. Paragraph two of Article 187 defines a qualified criminal offence. A criminal offence is qualified based on the status of either the victim or the perpetrator.

\footnotetext{
17 “(1) Whoever solicits another person to use narcotic drugs or illegal doping substances or provides a person with drugs to be used by him or by a third person, or whoever provides a person with a place or other facility for the use of narcotic drugs or illicit substances in sport shall be sentenced to imprisonment for not less than six months and not more than eight years. (2) Whoever commits the offence under paragraph 1 against several persons, a minor, mentally disabled person, person with a temporary mental disturbance, severe mental retardation or person who is in the rehabilitation, or if the offence is committed in educational institutions or in immediate vicinity thereof, in prisons, military units, public places or public events, or if the offence under paragraph 1 is committed by a civil servant, priest, doctor, social worker, teacher or educator, and thereby exploits his position, shall be sentenced to imprisonment between one and twelve years. (3) Narcotic drugs, illicit substances in sport and the tools for their consumption shall be seized. (4) The act referred to in paragraphs 1 and 2 shall not be unlawful if the perpetrator acts in accordance with the programme for addiction treatment or supervised use of drugs, which is approved in accordance with the law and carried out within or under the supervision of public health care."
} 
Paragraph four of Article 187 provides for the exclusion of illegality of the act referred to in paragraph one or two of this Article. No criminal offence is committed in the case of a legally approved programme of addiction treatment or the implementation of drug use control that is carried out or supervised by a public health authority (Deisinger, 2019: 344).

\section{Conclusion}

Although criminal offences against public health are statistically insignificant, statistics alone are sometimes misleading and in this case such offenses are important for protecting human health as one of the most significant rights protected by law. This author contends that the legal regulation of crimes against public health in the Republic of Slovenia is appropriate considering the country's circumstances.

Given the rapid development of medicine, it may be expected that in the future the need will arise for some new incriminations. Modern law places an increasing importance on an injured person's approval for interference with his or her body, which will lead to a different way of assessing the completeness of the essence of several criminal offences referred to in Chapter Twenty of the Slovenian Criminal Code. Against this background, this author recommends that the legislator monitor the developments and to amend the Criminal Code in accordance with the developments in the medical and legal fields.

\section{Legislation and legal documents}

Acquisition and Transplantation of Parts of the Human Body for Treatment Purposes Act, Uradni list Republike Slovenije [Official Gazette of the Republic of Slovenia], No. 56/15.

Convention for the Protection of Human Rights and Dignity of the Human Being with regard to the Application of Biology and Medicine: Convention on Human Rights and Biomedicine ETS No. 164, 04. 04.1997.

Council Framework Decision 2004/757/JHA of 25 October 2004 laying down minimum provision on the constituent elements of criminal acts and penalties in the field of illicit drug trafficking, Official Journal of the European Union L 335/8 of 11. 11. 2004.

Directive 2010/53/EU of the European Parliament and the Council of 7 July 2010 on standards of quality and safety of human organs intended for transplantation OJ L 2076.8 .2010 and Corrigendum OJ L 243 16.9.2010 and Commission Implementing Directive 2012/25/EU of 9 October 2012 OJ L 275/27 10. 10. 2012.

International Convention against Doping in Sport, 2005. The Republic of Slovenia ratified the Convention through the Act Ratifying the International Convention against Doping in Sport, Uradni list Republike Slovenije - Mednarodne pogodbe [Official Gazette of the Republic of 
Slovenia, International Conventions], No. 15/07.

Pharmacy Services Act, Uradni list Republike Slovenije [Official Gazette of the Republic of Slovenia], Nos. 85/16 and 77/17.

Single Convention on Narcotic Drugs, 1961 and Protocol amending the Single Convention on narcotic Drugs, 1961, 25 March 1972; Convention on Psychotropic Substances, 1971; United Nations Convention against Illicit Traffic in Narcotic Drugs and Psychotropic Substances, 1988. The Republic of Slovenia joined the aforementioned conventions on the basis of the Act on the Notification of Succession to United Nations Conventions and Conventions Adopted by the International Atomic Energy Agency, Official Gazette of the Republic of Slovenia, No. 9/92.

Statistical Office of the Republic of Slovenia: https://www.stat.si/StatWeb/Field/Index/10/60 (4 April 2019).

The Criminal Code (KZ-1), Uradni list Republike Slovenije [Official Gazette of the Republic of Slovenia], Nos. 55/08, 66/08, 39/09 (KZ-1A), 91/11 (KZ-1B), 54/15 (KZ-1C), 38/16 (KZ1D) and 27/17 (KZ-1E).

Veterinary Practice Act, Uradni list Republike Slovenije [Official Gazette of the Republic of Slovenia], Nos. 33/01 and 22/18.

\section{References}

Babić, M. \& Marković, I. (2018) Krivično pravo, Posebni dio, 5. izmjenjeno i dopunjeno izdanje (Banja Luka: Pravni fakultet Banja Luka).

Bavcon, L., Šelih, A. et al. (2013) Kažensko pravo, Splošni del, 6. izdaja (Ljubljana: Uradni list Republike Slovenije).

Bavcon, L. (2000) Malomarnostna kazniva dejanja v cestnem prometu: zamisel, struktura in problemi, Uveljavljanje novih institutov kazenskega materialnega in procesnega prava (Ljubljana: Uradni list Republike Slovenije).

Cvitanović, L. et al. (2018) Kąneno pravo, Posebni dio (Zagreb: Pravni fakultet Sveučilišta u Zagrebu).

Deisinger, M. (2017) Kazenski rakonik 2017, Posebni del s komentarjem, sodno prakso in literature (Maribor: Poslovna založba MB).

Korošec, D. (2019) In Korošec, D., Filipčič, K., \& Zdolšek, S. (eds.) Veliki zunanstveni komentar posebnega dela Kazenskega zakonika (KZ-1), 2. knjiga (177. do 256. clen) (Ljubljana: Uradni list Republike Slovenije and Pravna fakulteta Univerze v Ljubljani).

Korošec, D., \& Balažic, J. (2019) In Korošec, D., Filipčič, K., \& Zdolšek, S. (eds.) Veliki znanstveni komentar posebnega dela Kazenskega zakonika (KZ-1), 2. knjiga (177. do 256. člen) (Ljubljana: Uradni list Republike Slovenije and Pravna fakulteta Univerze v Ljubljani).

Mervič, K. Pitako, A., Valenčič, B., Korošec, D., \& Balažic, J. (2019) In Korošec, D., Filipčič, K., \& Zdolšek, S. (eds.) Veliki znanstveni komentar posebnega dela Kazenskega zakonika (KZ-1), 2. knjiga (177. do 256. člen) (Ljubljana: Uradni list Republike Slovenije and Pravna fakulteta Univerze v Ljubljani).

Mrčela, M., \& Vuletić, I. (2019) Liječnik i kazneno pravo (Zagreb: Narodne novine).

Pitako, A., Valenčič, B., \& Korošec, D. (2019) In Korošec, D., Filipčič, K., \& Zdolšek, S. (eds.) Veliki znanstveni komentar posebnega dela Kazenskega zakonika (KZ-1), 2. knjiga (177. do 256. clen) (Ljubljana: Uradni list Republike Slovenije and Pravna fakulteta Univerze v Ljubljani).

Pitako, A., Valenčič, B., Korošec, D., \& Balažic, J. (2019) In Korošec, D., Filipčičč, K., \& Zdolšek, S. (eds.): Veliki znanstveni komentar posebnega dela Kazenskega zakonika (KZ-1), 2. knjiga (177. do 256. člen) (Ljubljana: Uradni list Republike Slovenije and Pravna fakulteta Univerze v Ljubljani).

Šepec, M. (2019) In Korošec, D., Filipčič, K., \& Zdolšek, S. (eds.) Veliki znanstveni komentar posebnega dela Karenskega zakonika (KZ-1), 2. knjiga (177. do 256. clen) (Ljubljana: Uradni list Republike Slovenije and Pravna fakulteta Univerze v Ljubljani).

Valenčič, B., \& Korošec, D. (2019) In Korošec, D., Filipčič, K., \& Zdolšek, S. (eds.) Veliki znanstveni komentar posebnega dela Kazenskega zakonika (KZ-1), 2. knjiga (177. do 256. člen) (Ljubljana: Uradni list Republike Slovenije and Pravna fakulteta Univerze v Ljubljani). 